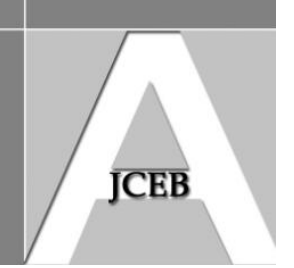

\title{
A Review of Productivity Analysis of the New Zealand Construction Industry
}

Malcolm Abbott, (Swinburne University of Technology, Melbourne, Australia)

Chris Carson, (UNITEC, Auckland, New Zealand)

\begin{abstract}
In recent years there has been a rising interest in the level of productivity and efficiency of the New Zealand construction industry. This interest has meant that there has been an increased use of statistical techniques to determine the productivity and efficiency of the overall industry. The purpose of this paper is to review the various measures that have been used to gauge the levels of productivity and efficiency in the New Zealand construction industry; as well as analyse some of the results to date. Finally, it considers potential areas for future research, including possible improvements to measurements techniques that maybe used.
\end{abstract}

Keywords: Productivity, Construction NZ

\section{Introduction}

In recent years a number of attempts have been made to identify the reasons for the lack of growth in productivity and income in New Zealand. One area where this lack of growth of productivity is most marked is in the case of the construction industry. Indeed, official statistics seem to indicate that the construction industry in New Zealand has a productivity level roughly comparable to what it was in the late 1970s (Statistics New Zealand, Industry productivity statistics). This has raised considerable concern in the industry itself, and more generally, about the degree to which the industry is operating below its full potential (New Zealand, Department of Building and Housing, Productivity Taskforce 2009; Van Dai Tran 2010; New Zealand Productivity Commission 2011). The possible reasons behind this low level of productivity in New Zealand are various and could include such things as low economies of scale in the industry, a lack of competition, regulatory impediments, faulty innovation and management practice, poor investment quality and a low levels of skills (Davis 2007).

The purpose of this paper is to review the various measures that have been used to gauge the levels of productivity and efficiency in the New Zealand construction industry and to make suggestions to how these measures might be improved. In meeting this objective the results of the past studies will be analysed in order to identify some of the issues surrounding the apparent stagnation of growth in productivity in the New Zealand construction industry. The manner in which this is approached is to compare the different approaches used and to then identify the pros and cons of the different approaches. The final task is to then suggest improved ways to determine productivity change of the New Zealand construction industry that would take account of the difficulties that were identified in the previous approaches used.

More improved measures of productivity of the construction industry would be useful as the construction industry constitutes a substantial part of the New Zealand economy. Furthermore in recent years there has been a concern that this sector has been a relatively stagnant one. More improved measures would assist policy makers and industry leaders to determine ways to improve the performance of this industry. 
The paper is structured as follows. In the first section a broad description of the condition of the New Zealand construction industry is given. This is followed by a section that examines the various ways in which productivity can be assessed and some of the issues involved in doing so. A section is provided that examines past studies of productivity in the construction industry in New Zealand and in the final section some conclusions are made.

\section{The Construction Industry in New Zealand}

The construction industry constitutes a significant part of the New Zealand economy. In 2010 the industry made up over four per cent of New Zealand's GDP and employed over eight per cent of the employed workforce (Table 1). This high level of employment compared to output reflects the relative labour intensity of the industry.

\begin{tabular}{|l|c|c|c|c|}
\hline & GDP & GDP & Employment & Employment \\
\hline & $\begin{array}{c}\text { Constant } \\
1995 / 96 \$ \mathrm{~m}\end{array}$ & $\%$ & 000 & $\%$ \\
\hline Agriculture, fishing, forestry and mining & 9,980 & 7.7 & 150.2 & 6.9 \\
\hline Manufacturing & 16,395 & 12.7 & 247.8 & 11.5 \\
\hline Electricity, gas and water & 2,634 & 2.0 & 14.4 & 0.7 \\
\hline Construction & 5,521 & 4.3 & 178.8 & 8.3 \\
\hline Wholesale trade & 9,374 & 7.2 & 103.7 & 4.8 \\
\hline Retail accommodation and restaurants & 9,901 & 7.6 & 333.7 & 15.4 \\
\hline Transport and Communication & 13,891 & 10.7 & 135.4 & 6.3 \\
\hline Finance, business \&personal and & 55,061 & 42.5 & 869.3 & 40.2 \\
\hline community services. & 6,754 & 5.2 & 121.2 & 5.6 \\
\hline Government administration and defence & 129,511 & 100.0 & 2163.4 & 100.0 \\
\hline
\end{tabular}

Table 1 Gross Domestic Product and employment by industry, 2010, Annual (March years) Source: Statistics New Zealand, Gross Domestic Product; Household Labour Force Survey

Growth of the construction industry was solid from the late 1990s and through most of the 2000s, but tapered off in the last few years of the 2000s (Figure 1). Over the longer term the construction sector has grown at a similar rate to the rest of the New Zealand economy, driven by rising incomes and population growth, although there is evidence that the growth of the industry is more volatile than that of the economy in general (Figure 1).

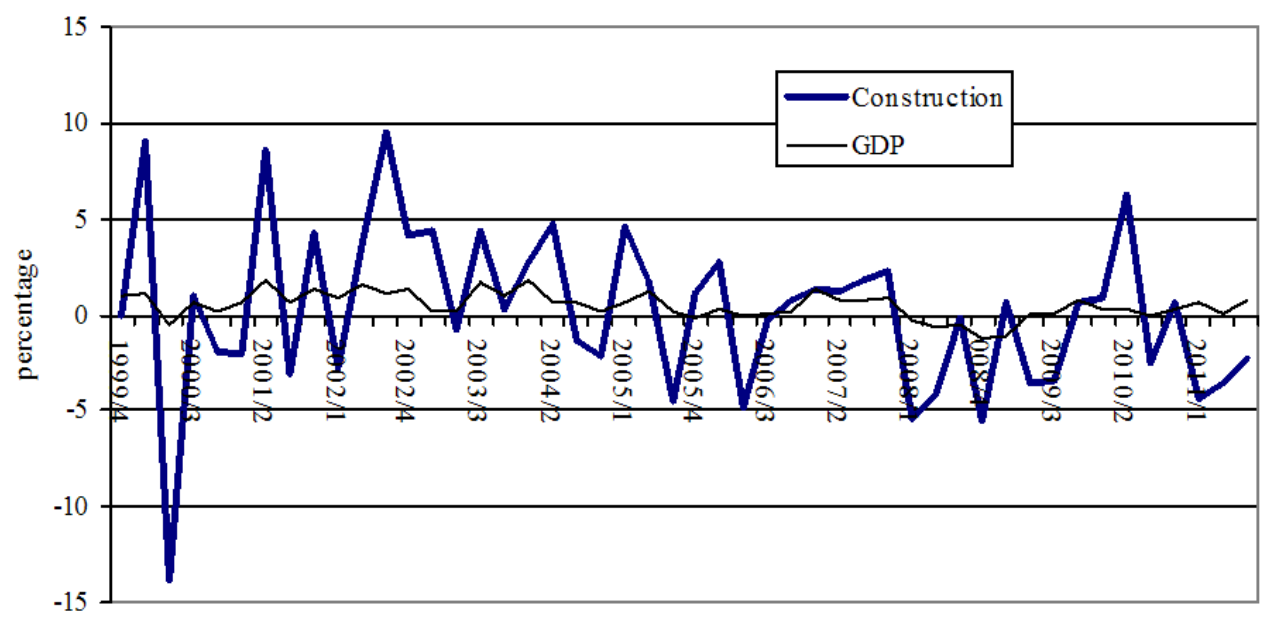

Figure 1 Quarterly growth of GDP and construction in New Zealand Source: Statistics New Zealand, Gross Domestic Product

Abbott, M and Carson, C (2012) 'A review of productivity analysis of the New Zealand construction industry', Australasian Journal of Construction Economics and Building, 12 (3) 1-15 
The construction sector is broadly speaking divided into three sub-sectors:

- Residential building (houses, units, flats);

- Non-residential building (offices, shops, hotels);

- Engineering construction (roads, bridges, water sewerage).

The private sector operates predominately in the construction of residential and non residential building, whereas the public sector operates primarily in engineering construction. Some major engineering projects are delivered through public-private partnerships, which in its simplest form is a contractual agreement between the government and private sector for the delivery of public infrastructure.

Despite the growth of the construction industry and its importance to the generation of employment in New Zealand, there has been a growing concern that the sector has been a stagnant one in recent times in terms of growth of productivity. Indeed some studies have found that the sector's level of productivity is no higher than it was in the late 1970s (Figure 2). A Building and Construction Sector Productivity Taskforce, for example, was established in 2008 as a joint measure of the industry and government in New Zealand to investigate the limited productivity gains in the sector in recent years and reported a number of reasons why this had been the case (New Zealand, Department of Housing Productivity Taskforce 2009).

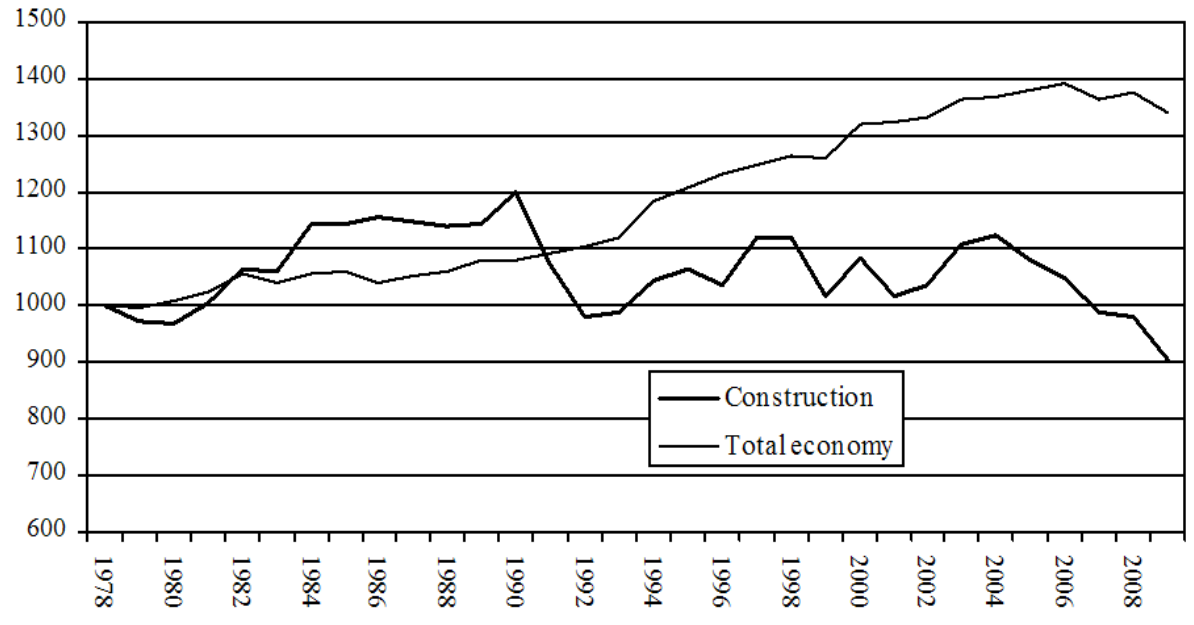

Figure 2 Productivity indexes of construction and the New Zealand economy, 1978 to 2009 Source: Statistics New Zealand, Industry Productivity Statistics

In the past there has been some research undertaken that looks at the growth of productivity of the construction industry at the sector level. Most of this past work has been undertaken as part of larger work looking at productivity growth of the larger economy, but in recent times some more focused work has been undertaken (see Table 2). To understand the past work that has been undertaken it must first be understood just what approaches can be made to the analysis of productivity. Furthermore it is important to policy makers and industry leaders that future productivity analysis accurately reflects changes in the industry and does not give a distorted picture of what is occurring. Finally accurate measures can help to raise our understanding or what drives productivity change in the industry, or conversely impedes it.

\section{Traditional Efficiency and Productivity Measures}

To understand how productivity analysis has been used in the past to determine change in the New Zealand construction over time it is important to understand the different ways in which this can be estimated. The way in which the productivity and efficiency of the construction industry has been analysed in the past has been influenced by the way in which 
productivity analysis has developed more generally over the years. Structural reform of the economy by various governments has encouraged the study of the productivity and efficiency performance of a variety of industries and government service providers. In undertaking this research a range of productivity and efficiency techniques have been used.

To begin with, efficiency can be defined as being the degree to which resources are used in an optimal way to produce outputs of a given amount. At the level of an industry there are three main aspects of economic efficiency: allocative, technical, and scale (Farrell 1957). Allocative efficiency indicates the factor input proportions given relative input prices. An allocatively efficient industry produces using the lowest cost combination of inputs. Technical efficiency takes place when the maximum output possible is delivered using given inputs (labour, capital, and other inputs). Scale efficiency refers to optimal size of an industry (and firms within it). It could be that an industry may be allocatively and technically efficient, but may still be producing too little or too much output. Economic efficiency is a combination of allocative and technical and scale efficiency. It helps to identify whether cost reductions can be made.

Productivity change differs from efficiency in that it is a dynamic indicator of the change in the ratio of outputs to inputs over time. Productivity growth reflects changes in allocative and technical efficiency, technological and managerial improvements and changes in the external environment in which the production of an industry occurs. When an industry improves its efficiency, it moves towards a best practice frontier, and in doing so also increases its productivity. When the frontier also shifts outwards, due say to technological change, then productivity also rises.

Over the years a range of different measures have been developed to quantify how efficiency and productivity levels change over time. These measures include the calculation of indexes, the estimation of cost and production functions, data envelopment analysis and stochastic frontier measures. Most of these types of measures have been used in the past to analyse changes in the New Zealand construction industry.

\section{Partial and Total Factor Productivity Index Measures}

The initial way in which productivity changes over time were measured was by using an 'index' approach. The index approach involves the estimation of index numbers, which can be used to indicate the partial or total factor productivity change of an industry over time. Partial productivity measures generally show the ratio of an index of an industry's output to an index of a single input factor. In the case of the construction industry, for example, an index of the volume of construction activity per employee is a labour-based partial productivity measure.

Partial productivity indicators have the advantage of being easy to compute, require only limited data and are intuitively easy to understand. This has meant that they are used very commonly in a range of different industries. Unfortunately they can also be misleading when looking at the change in productivity of an industry over time. It might, for instance, be possible for an industry to raise productivity with respect to one input at the expense of reducing the productivity of other inputs. Partial indices of output to labour, for instance, often tend to overstate the growth of total productivity because over time the use of capital as an input substitutes for labour. A further problem is that capital productivity measures are difficult to calculate given the difficulty that often occurs in measuring capital inputs, and the often very long life of some assets.

Total factor productivity indexes were developed to overcome the problem of the substitutability of inputs. Total factor productivity measures are the ratio of a total aggregate output quantity index to a total aggregate input quantity index. The index approaches used to combine outputs and inputs that might be used include the Laspeyres, Paasche, or Fisher 
approaches. A Tornqvist index approach has been used in many total factor productivity studies. Total factor productivity growth, therefore, is the difference between the growth of the output and input indices.

Although there are a few studies of industry level total factor productivity in the construction industry the literature is not as extensive as it is in many other industries. Most research on construction industry productivity tends to be concerned more with site level labour productivity, which has a more direct relevance to industry management (Ganesan 1984; Lowe 1987; Maloney 1983; Allen 1985; Thomas, Maloney, Horner, Smith, Handa and Sanders 1990; Thomas and Sakarcan 1994). Despite this some measures of the total factor productivity of construction were developed using the index approach. On the whole this occurred as part of efforts to establish the growth of productivity for the entire economy and other industry sectors, rather than exclusively for the construction sector.

Total factor productivity indexes were first developed at the National Bureau of Economic Research in the United States in the late 1940s. Initially studies were undertaken of labour productivity for a range of different industries (including construction). This was followed by the estimation of a range of other non-labour partial productivity measurements such as for capital and in the case of agriculture land and livestock. A range of studies were then undertaken that attempted to combine the various types of inputs together in a similar fashion to the way in which earlier researchers like Simon Kuznets and Colin Clark had for output in determining levels of Gross National Product. In undertaking this work the research by Stigler (1947; 1961), Barton and Cooper (1948); Kendrick and Jones (1951), Schmookler (1952), and Fabricant (1954) were important. Starting with agriculture this work spread to other sectors of the economy as well as national wide studies. By the mid-1950s the National Bureau of Economic Research had published a great deal of work using total factor productivity indexes for a range of industries (Kendrick 1956a, 1956b, 1961, 1973). As part of this work total factor productivity indexes were also determined for the construction industry. Over the years studies have also been conducted in a range of other countries besides the United States using the index approach (see for instance Hong Kong; Chau and Walker 1988; Chau 1990 and Singapore: Tan 2000).

In the case of the New Zealand construction industry examples of partial productivity indexes include those by Marks (1984), Davis (2007), Janssen and McLoughlin (2008) and the New Zealand Institute of Economic Research (2011), who all estimated New Zealand labour productivity figures. In terms of total factor productivity indexes there have been a number of main works undertaken on the New Zealand construction industry as part of economy wide productivity estimates. These are by Diewert and Lawrence (1999), Black, Guy and McLellan (2003), and Statistics New Zealand, Industry productivity statistics (2011).

\section{Econometric Measures - Cost and Production Functions}

The index approach to determining total factor productivity assumes that the ratio of inputs used and products produced are kept constant over time. As this seems unrealistic other methods were developed. Econometric methods involve the estimation of cost or production functions. The estimated function can then be used to identify changes in productivity or efficiency. The estimation of cost functions has been the most commonly used method of determining the levels of efficiency in the industry, although a number of techniques have been used in estimating cost functions. This approach is also often referred to as the Growth Accounting Approach.

Dacy (1965) was perhaps the first to use an estimated production function for the United States construction industry (1947 to 1963) and found increasing levels of productivity. Later examples of estimated production functions include those by Allen (1985); Stokes (1981) Goodrum and Haas (2004), Schiver and Bowlby (1985), Mao, Goh, Wang and Ofori (2003) and Kau and Sirmans (1983). Examples of the use of cost functions estimations include 
those by Chau (1993) and Chau (2009) who in both cases found rising productivity levels in Hong Kong; and Schriver and Bowlby (1985).

In the New Zealand case a number of researchers used the growth accounting approach to estimate productivity over time by estimating production functions. These include the studies of Orr (1989), Chapple (1994), Philpott (1995), and Mason and Osborne (2007). In each case they made estimates at the national level and then broke down productivity into various industry sectors including that of construction.

One difficulty that arises in using either the index approaches or econometric approaches is that it relies upon there being reliable, market determined prices for both inputs and outputs. In the case of industries such as the utilities where market power distorts prices, and in government service delivery where output prices are often subsidised or non-existent there arose a need to develop productivity measures that was not so reliant on price data. This led to the development of Data Envelopment Analysis (DEA).

\section{Data Envelopment Analysis (DEA) and Stochastic Frontier Measures}

DEA was pioneered by Charnes et al (1978) based on the work by Farrell (1957) and there are now many texts offering a detailed discussion on DEA, including the algorithms used (see, for example, Lovell and Schmidt (1988), Färe, Grosskopf and Lovell (1985) and Coelli, Rao and Battese (1998)). Data envelopment analysis (DEA) is a linear programming technique which estimates organisational efficiency by measuring the ratio of total inputs employed to total output produced for each unit. This ratio is then compared to others in the sample group to derive an estimate of relative efficiency. DEA identifies the most efficient providers of a good or service by their ability to produce a given level of output using the least number of inputs. Other units in the sample group receive an efficiency score determined by the variance in their ratio of inputs employed to outputs produced relative to the most efficient unit in the sample group. DEA is therefore a measure of relative efficiency against the sample group's benchmark best practice. The advantage is that it can be used without input or output prices, which is useful where data of this sort is not available. As well as being used to benchmark units against one another it is possible to use DEA to estimate changes in productivity of individual units, or the sample as a group, over time.

DEA has been used extensively in a number of industries to assess productivity and efficiency levels (especially utilities). In the case of the construction industry only a fewer number have been undertaken, The DEA approach was used in the case of Hong Kong construction by Chau and Wang (2005), Wang (1998); Wang and Chau (1997, 2001). Each study found a rising level of productivity there. In the case of New Zealand a single study by Fare, Grosskopf and Margaritis (1996) has been undertaken.

Stochastic frontier measures involve the use of parametric techniques to estimate technical efficiency by constructing first the production frontier derived from the best practice firms and then comparing the actual output of firms relative to the best practice firms. Studies of this sort in the construction industry are rare and in the case of the New Zealand industry have not to date been undertaken.

Although markets for construction tend to be fairly competitive and more market driven than the case of the utilities and government service provision there have been concerns that prices in these markets do face some distortions. For this reason the studies previously mentioned made use of the DEA approach at determining changes to productivity over time.

\section{Issues}

In addition to the need to use total factor indicators to determine productivity change over time rather than partial indicators and the possible need to use indicators that don't rely so 
much on price data a number of other issues have arisen. Most studies that look at the productivity of the construction industry are centred on the industry in the United States. One element some researchers found was that there appeared to be a degree of stagnation or decline in productivity in the United States construction industry during the 1970s and 1980s. These include work by Stokes (1981), Allen (1985) and Schriver and Bowlby (1985). These researchers had some difficulty explaining why this might have occurred, given that it was a period of some technological change and innovation in the industry. Tan (2000) found a similar decline in productivity in the Singapore construction industry over the period 1980 to 1996, and Mao, Goh, Wang and Ofori (2003) found Singapore had a slow rate of growth between 1984 and 1998. The explanations of this perceived stagnation are of some interest to New Zealand researchers as a similar stagnation has been detected in this country.

In the American context some thought that this decline could be explained by the use of inappropriate price indexes (Dacy 1965; Stokes 1981). In addition a more influential view expressed at the time in the United States was that construction was largely a labour intensive industry and the introduction of new equipment and materials could only increase outputs with a given level of labour and capital. Rosefielde and Mills (1979), in contrast, argued that official data did not fully account for changes in quality and so tried to adjust for changes in the scale and structure of the quality of output. They argued that as construction is immobile and designed to achieve some particular function, at some specific site, a diverse and changing type off output is produced by the industry. This coupled with a changing composition of materials makes it difficult to measure quality improvements over time, which in turn leads to an underestimation of output levels, and therefore productivity improvements. In using quality adjusted figures for output Rosefielde and Mills relied upon the work of Cassimatis who used the number of rooms per dwelling and square footage of buildings as an indicator of the quality of output.

In the New Zealand case past studies have all used some constant dollar valuation of the industry's production as an in indication of output, which assumes that this value reflects any changes that are occurring in quality and size, whether it be in terms of area or other form of quality. This might, perhaps, be a fair assumption but nowhere has it been justified. Indeed over the periods looked at by analysts the average size of both residential and commercial properties has risen considerably. It is notable that unlike countries like Australia, quality adjustments for the residential building industry are not included in the New Zealand estimation of construction value added (Bollard and Barrow 2012). As most New Zealand studies on productivity use some estimation of value added of the construction industry as the indicator of output it is possible that these studies significantly underestimate New Zealand productivity growth.

Schriver and Bowlby also found that much of the fall in productivity could be attributed to a change in the output mix from high to low productivity building projects. One problem in the New Zealand case is that the past studies have all bundled construction together as a single industry and do not attempt to break it up into its various components (residential, large engineering projects and commercial property). Therefore no attempt has been made to account for either changes in quality of changes in the composition in the output mix.

In light of the issues that have arisen in determining productivity change of the construction industry more generally a number of measures can be undertaken. First all a total factor rather than partial approach should be undertaken. Secondly it is necessary to use an approach like DEA or the stochastic approach along with any index or econometric approach to see if there are any price distortions that are important. Finally any approach should try to make use of physical values of output, along with monetary ones, in order to ensure that distortions to the estimates of productivity change are not being made. Bearing in mind these issues it is possible to observe how productivity analysis has been conducted in the New Zealand case. 


\section{Past Measures of Productivity in the New Zealand Construction Industry}

Since the 1980s a number of economists in New Zealand have made estimates of New Zealand's productivity change over the longer term. Notable examples include Marks (1984), Orr (1989), Smith and Grimes (1990), Chapple (1994), Philpott (1991, 1993, 1995), Sarel (1996), Grubb, Jackman and Layard (1982), ${ }^{1}$ Fare, Grosskopf and Margaritis (1996) and Conway and Hunt (1998). In some of these cases sectoral productivity was also identified, including that of the construction sector (i.e. Chapple; Philpott; Fare, Grosskopf and Margaritis). Further work was initiated from 1999 onwards by government agencies as well (Diewert and Lawrence 1999; Black, Guy \& McLellan; and Janssen \& McLoughlin (2008).

It should be remembered that all the studies, with one exception (Davis 2007), undertook a study of construction productivity as part of broader works on productivity of the New Zealand economy as a whole. In none of these cases, therefore, was any attempt made to adapt the methods used to account for any special conditions in the construction industry (such as quality adjustments). The separate studies on the New Zealand construction industry are listed in Table 2.

The first work undertaken was by Marks (1984), which used an index approach to determine labour productivity growth in New Zealand between 1965/66 and 1980/81. Marks' work was published in a work by the New Zealand Institute of Economic Research (NZIER) on the Labour Market, funded by the Social Science Research Fund Committee of the New Zealand Government. Marks was concerned with analysing the slowdown in labour productivity in all industries that had occurred in New Zealand from the early 1970s. As well as national figures, however, she also looked at a number of sectors of the New Zealand economy, including construction. In the case of the construction industry labour productivity was found to have increased at a, steady rate through the 1960s and 1970s.

Marks's work was followed by three related works, which all used a growth accounting approach to calculate total factor productivity change along with labour and capital productivity changes (Orr 1989; Chapple 1994; Philpott 1995). These studies were undertaken as part of a joint project between the NZIER and the Institute of Policy Studies of the Victoria University, Wellington (for the Ministry of Commerce). Orr's work was the first of these and his work and was later followed by work by Chapple (1994). Both Orr and Chapple worked for the NZIER which was to retain an interest in productivity analysis and as late as 2011 published work on this theme (NZIER 2011).

Orr's work ranged from 1961 to 1986 and found that total factor productivity rose over the period at an annual average of 1.75 percent (Labour productivity: 2.30 percent, Capital productivity: 1.02 percent). Chapple's work ranged from 1971 to 1991 and showed a rise in annual average productivity of 0.7 per cent over the entire period (1.0 per cent for labour productivity and 0.2 per cent for capital productivity). Both estimated a Cobb-Douglas production function and equated one output to that of the inputs of labour hours and net capital stock, using capital stook figures developed by Philpot. Orr's work confirmed Marks' earlier findings that productivity rose steadily during the 1960s and early 1970s. Chapple also found that productivity rose in the early 1970s. Both Orr and Chapple also found that productivity tended to peak in the years of construction booms in 1975/76 and then again in 1986/87. At much the same time Philpott worked on similar figures for the period 1960 to 1995 (Chapple 1991, 1993, 1995). He looked at twenty separate industries including construction. His results were similar to that of Chapple and Orr, in that he found that productivity growth was steady up until 1975, stagnated somewhat after that and surged during periods of construction boom and flagged during recessions.

\footnotetext{
${ }^{1}$ Sarel (1995) and Grubb, Jackman and Layard (1982) both undertook studies on New Zealand productivity growth as part of wider studies of growth of the OECD countries.
}

Abbott, M and Carson, C (2012) 'A review of productivity analysis of the New Zealand construction industry', Australasian Journal of Construction Economics and Building, 12 (3) 1-15 
Figure 3 provides an overview of these works on productivity of the construction industry. As can be seen productivity tended to rise through the 1960s and early years of the 1970s before peaking around 1976 and then declining. A recovery in productivity took place in the early 1980s. Despite the decline in productivity in the late 1970s the situation in the late 1980 s still seemed to be a relatively good one. The productivity of the industry tended to rise over the twenty-five year period (1960 to 1985) and this is reflected in the works of Marks, Orr, Chapple and Philpott who all recorded increases in total factor productivity of the construction industry (Table 2).

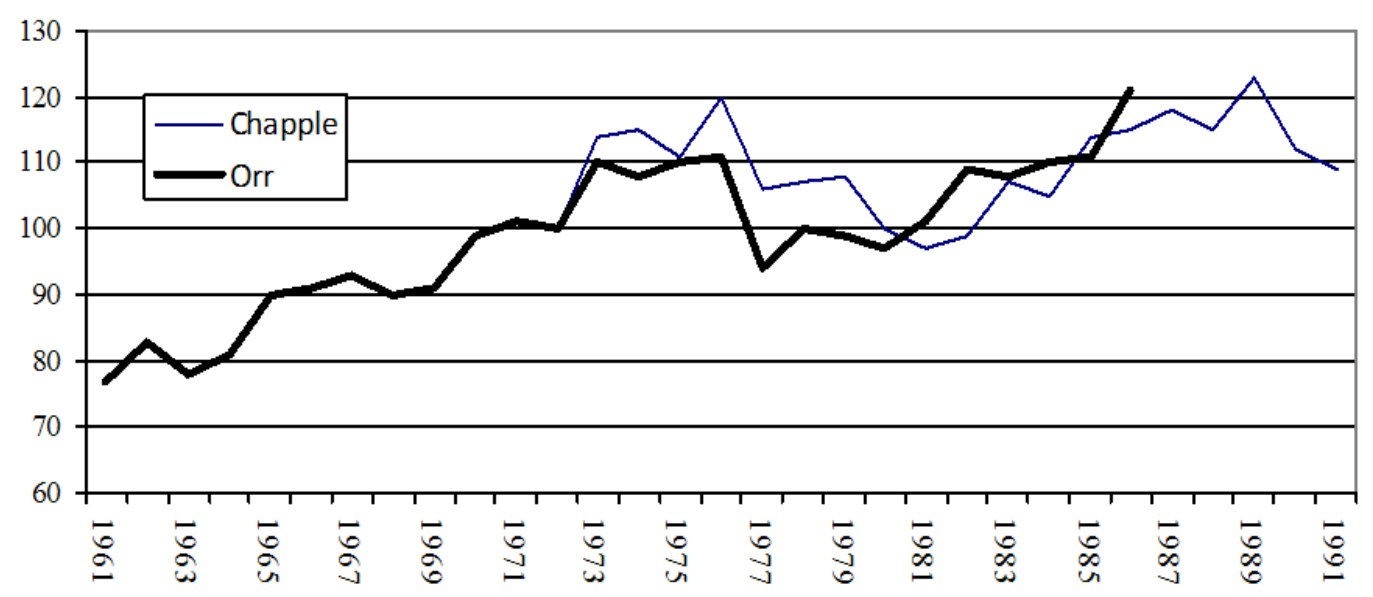

Figure 3 Total factor productivity in New Zealand construction, 1972=100 Source: Orr 1989; Chapple 1994

The first study to come to more pessimistic conclusions was that of Fare Grosskopf and Margaritis (1996). These economists used a different approach and undertook a study on a national basis and looked at twenty industries (including construction). They used the DEA approach and equated value added as the output to labour hours and capital using the perpetual inventory method as the input for the years 1973 to 1994 . They found for construction that although productivity rose slightly between 1973 to 1984 (annual average of 0.3 per cent) it declined over the period 1984 to 1994 (-1.2 per cent). For the entire economy between 1973 and 1974 productivity rose by 1.46 per cent, mainly due to technological change rather than efficiency changes. Because their study concentrated more on the period from the mid 1970s onwards their results overall showed stagnation in the growth of construction productivity.

In 1999 Diewert and Lawrence - in work commissioned by the Department of Labour, the Reserve Bank of New Zealand and the Treasury - used labour hours and net capital stock (valued using a user cost formula which accounted for depreciation, a rate of return and capital gain) as inputs and an index of total national output to compute labour productivity, capital productivity and a total factor productivity between the years 1972 and 1998. In doing so it used the index number approach. In this work the construction sector showed a worse performance compared to other sectors, although it enjoyed a trend annual total factor productivity growth of 0.6 per cent although it was the subject of cyclical downturns, especially in 1980 and 1993 (Diewert and Lawrence 1999, p. 74).

Statistics New Zealand received funding from the Growth and Innovation Framework in 2003 to develop official productivity statistics for New Zealand. In doing so they built on the earlier work undertaken by Diewert and Lawrence (1999) and Black, Guy and McLellan (2003).

The results of the work by Diewert and Lawrence, Black, Guy and McLennan and Statistics New Zealand are all summarised in Figure 4. In each case productivity does seem to have stagnated across the whole of the period covered with especially low levels of productivity 
encountered during the recessions of the late 1970s and early 1990s. There does, therefore, seem to some evidence that productivity in the construction industry correlates to business cycles.

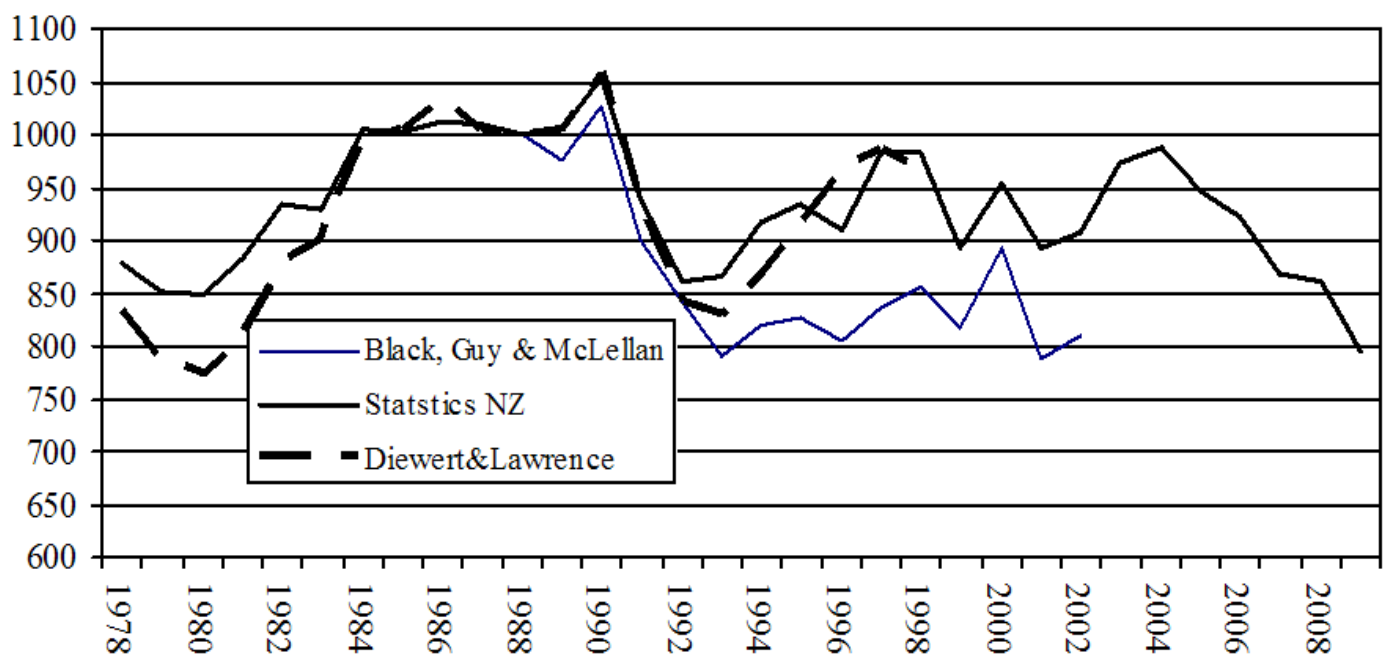

Figure 4 Total factor productivity of the New Zealand construction, 1978=1000 construction industry

Source: Statistics New Zealand 2011; Diewert \& Lawrence 1999, Black, Guy \& McLellan 2003

Additional studies have been undertaken by Janssen and McLoughlin (2008), Davis (2007), and Mason and Osborne (2007). Each of these studies has tended to concentrate on the periods from the mid-1990s to the end of the 2000s. Given that these studies miss the downturns in productivity of the early 1990s and late 2000s they tend to provide more positive results.

Regardless of the periods selected it appears from the various studies that although productivity increased to some degree up until the mid-1970s, since then the results have been mixed. This appears to be the case even though there have certainly been a range of technological changes that have occurred in the industry since then. New tools and equipment have been introduced that have tended to be labour savings. This has meant the introduction of hand held powered tools (nail drivers, sanders, saws and drills), and improved lifting and moving machinery (cranes, loaders, earth movers, graders, forklifts). New materials and processes have also been introduced along with a greater use of prefabricated materials.

The introduction and greater use of new equipment, materials and processes has meant that it is hard to explain why growth in the productivity of the New Zealand construction industry has been sluggish. It is possible that the various studies of productivity growth may have underestimated the growth in output of the industry, and therefore productivity, for the reasons explained by Rosefielde \& Mills, and Schriver \& Bowlby; namely the lack of quality adjustments in value added data and the shift of construction from high productivity to low productivity activities. In the future, therefore, it would be useful if studies made greater use of output measures that have some quality adjustment, and that greater use is made of techniques that rely less on pricing. 


\begin{tabular}{|c|c|c|c|c|}
\hline AUTHOR(S) & DATE & MEASURES & $\begin{array}{l}\text { PERIOD } \\
\text { STUDIED }\end{array}$ & APPROACH, VARIABLES \& RESULTS \\
\hline Marks & 1984 & Labour productivity & $\begin{array}{l}1965 / 6 \text { to } \\
1980 / 1\end{array}$ & $\begin{array}{l}\text { Index approach } \\
\text { Output: Sectorial real GDP. Input: Labour employed } \\
\text { LP: } 1.0 \% \text { per annum }\end{array}$ \\
\hline Orr & 1989 & $\begin{array}{l}\text { Partial and total factor } \\
\text { productivity }\end{array}$ & 1961 to 1986 & $\begin{array}{l}\text { Growth Accounting - Production function } \\
\text { Output: gross domestic product. Inputs: employed, net capital stock } \\
\text { TFP: } 1.75 \% \text { per annum (LP: } 2.30 \% ; \text { KP: } 1.02 \% \text { ) }\end{array}$ \\
\hline Chapple & 1994 & $\begin{array}{l}\text { Partial and total factor } \\
\text { productivity }\end{array}$ & 1972 to 1991 & $\begin{array}{l}\text { Growth Accounting Production function } \\
\text { Output: value added. Inputs: labour hours, net capital stock } \\
\text { TFP: } 0.7 \% \text { per annum (LP: } 1.0 \% \text { KP: } 0.2 \% \text { ) }\end{array}$ \\
\hline Philpott & 1995 & Total factor productivity & 1960to1994 & $\begin{array}{l}\text { Growth Accounting Production function } \\
\text { Output: Sectorial real GDP. Inputs: employed, average of gross \&net capital stock. } \\
\text { TFP: } 0.3 \% \text { per annum (LP: } 1.0 \% \text {; KP: }-1.4 \% \text { ) }\end{array}$ \\
\hline $\begin{array}{l}\text { Fare, } \\
\text { Grosskopf \& } \\
\text { Mararitis }\end{array}$ & 1996 & Total factor productivity & 1973 to 1994 & $\begin{array}{l}\text { DEA approach } \\
\text { Output-value added. Inputs-labour hours, net capital } \\
\text { TFP: }-0.4 \% \text { per annum }\end{array}$ \\
\hline $\begin{array}{l}\text { Diewert \& } \\
\text { Lawrence }\end{array}$ & 1999 & $\begin{array}{l}\text { Partial and total factor } \\
\text { productivity }\end{array}$ & 1978 to 1998 & $\begin{array}{l}\text { Index approach } \\
\text { Inputs: labour hours and net capital stock. } \\
\text { TFP: }-0.4 \% \text { per annum }\end{array}$ \\
\hline $\begin{array}{l}\text { Black, Guy \& } \\
\text { McLellan }\end{array}$ & 2003 & $\begin{array}{l}\text { Partial and total factor } \\
\text { productivity }\end{array}$ & 1988 to 2002 & $\begin{array}{l}\text { Index approach } \\
\text { Output: sectorial real GDP. Inputs: labour hours, net capital stock } \\
\text { TFP: }-1.51 \% \text { per annum }\end{array}$ \\
\hline $\begin{array}{l}\text { Janssen \& } \\
\text { McLoughlin }\end{array}$ & 2008 & Labour productivity & 1989 to 2007 & $\begin{array}{l}\text { Index approach } \\
\text { Output: sectorial real GDP. Inputs: labour hours. } \\
\text { LP: }-3.1 \% \text { per annum }\end{array}$ \\
\hline Davis & 2007 & Labour productivity & 1997 to 2006 & $\begin{array}{l}\text { Index approach } \\
\text { Output: sectorial real GDP. Input: labour hours } \\
\text { LP: } 0.3 \% \text { per annum }\end{array}$ \\
\hline $\begin{array}{l}\text { Mason \& } \\
\text { Osborne }\end{array}$ & 2007 & $\begin{array}{l}\text { Labour and total factor } \\
\text { productivity }\end{array}$ & 1995 to 2004 & $\begin{array}{l}\text { Growth Accounting Production function } \\
\text { Output-Real value added. Inputs: labour hours and net capital stock } \\
\text { TFP: } 1.12 \% \text { per annum (LP: } 0.84 \% \text { per annum) }\end{array}$ \\
\hline NZIER & 2011 & Labour productivity & 1989 to 2006 & $\begin{array}{l}\text { Index approach } \\
\text { Output: value added. Input: labour employed, net capital stock } \\
\text { TFP }\end{array}$ \\
\hline $\begin{array}{l}\text { Statistics New } \\
\text { Zealand }\end{array}$ & 2011 & $\begin{array}{l}\text { Partial and total factor } \\
\text { productivity }\end{array}$ & 1978 to 2009 & $\begin{array}{l}\text { Index approach } \\
\text { Output: Sectorial real GDP. Inputs: labour hours, flow of capital services generated by capital } \\
\text { TFP: }-0.2 \% \text { per annum (LP: } 0.4 \% ; K P:-1.9 \% \text { ) }\end{array}$ \\
\hline
\end{tabular}

Table 2 Past studies on the productivity of the New Zealand construction industry 


\section{Summary}

Over the years there has been an interest in the performance of the construction industry in New Zealand and its contribution to national output. In this paper we have reviewed the various measures that have been used to gauge the levels of productivity growth in the industry and some of the key findings, as well as made recommendations on improved measures.

From the past research that has been undertaken to date on the productivity growth of the New Zealand construction industry a few conclusions can be made. The first of these is that in all probability growth in productivity in the industry was higher in the 1960s and early 1970 s then it was in subsequent decades. The apparent stagnation that occurred since the mid 1970s, however, might not have been as great as it first appears given that some form of value added, rather than quality adjusted measure of output, has always been used. Even given the difficulties associated with determining levels of output, productivity growth in the industry probably was greater in the period up until 1975.

The second factor that can be identified from past studies is the strong cyclical nature of productivity in the industry. Strong periods of growth in productivity in the industry are associated with strong periods of growth in demand. Sharp falls in productivity are also associated with slumps in building activity and recessions. This is especially true during the recessions in New Zealand of the early 1980s and early 1990s. Typically in industries productivity slumps during recessions because companies have to regard some of labour and most of their capital as fixed and so output slumps relative to inputs. During boom periods the opposite occurred. One associated problem with this phenomenon is that those studies that cover only a limited number of years are generally dominated by the predominate business cycle (i.e. boom or recession). Any study of productivity change in the construction industry in New Zealand really has to cover a long period of time if it is to net out the impact of cyclical fluctuations.

Finally no attempt has been made in the New Zealand context to determine if there is any reallocation within the construction industry of activity from high to low productivity areas of activity which might be affecting estimates. It appears that research stills needs to be undertaken in these areas in the future if we are going to be able to make informed inferences about the performance of the industry in terms of productivity. In particular greater use of quality adjusted outputs and less reliance on techniques that require reliable data on prices would be useful.

\section{References}

Allen, S.G. (1985) 'Why construction industry productivity is declining', Review of economic statistics, 117 (4), 661-665

Alterman, J. and E.E. Jacobs (1961) 'Estimates of real product in the United States by industrial sector, 1947-1955, Output, input and productivity measurement, National Bureau of Economic Research, Princeton University press

Barton, G.T., and M.R. Cooper (1948) 'Relation or agricultural production to inputs', Review of economics and statistics, 30 (7), 117-126

Black, M., Guy, M. and N. McLellan (2003) Productivity in New Zealand 1988 to 2002, Treasury Working paper 03/06, Wellington, The Treasury

Bollard, A. and R. Barrow (2012) 'Could we be better off than we think?' Reserve Bank of New Zealand, Speech to a meeting of the Trans-Tasman Business Circle, Auckland, 17 February 
Chapple, S. (1994) 'Searching for the Heffalump?', An exploration into sectoral productivity and growth in New Zealand', New Zealand Institute of Economic Research Working paper 99/10, Wellington. May

Charnes, A., W.W. Cooper and E. Rhodes (1978) 'Measuring the efficiency of decision making units, European journal of operational research, 2 (6), 429-444

Chau, K.W. (1990) Total factor productivity of the building industry of Hong Kong, unpublished PhD thesis, University of Hong Kong, Hong Kong

Chau, K.W. (1993) 'Estimating industry-level productivity trends in the building industry from building cost and price data', Construction management and economics, 11 (4), 370-383

Chau, K.W. (2009) 'Explaining total facto productivity trend in building construction: empirical evidence from Hong Kong', International journal of construction management, 45-54

Chau, K.W. and A. Walker (1988) 'The measurement of total factor productivity of the Hong Kong construction industry', Construction management and economics, 6 (3), 209-224

Chau, K.W. and Y.S. Wang (2005) 'An analysis of productivity growth in the construction industry: a non-parametric approach', in Khosrowshahi, F. ed. $21^{\text {st }}$ Annual ARCOM conference, 7-9 September 2005, SOAS, University of London, Association of Researchers in Construction Management, 1, 159-69

Coelli, T., D.S. PrasadaRao and G. E. Battese (1998) An introduction to efficiency and productivity Analysis, Boston, Kluwer

Conway, P. and B. Hunt (1998) 'Productivity growth in New Zealand: economic reform and the convergence hypothesis', Reserve Bank of New Zealand, internal paper, Economics Department, February

Dacy, D.C. (1965) Productivity and price trends in construction since 1947', Review of economics and statistics, 47 (4), 406-411

Davis, N. (2007) Construction sector productivity scoping report, Wellington, Martin Jenkins

Diewert, E. and D. Lawrence (1999) Measuring New Zealand's productivity, Treasury working paper 99/5, Wellington, Treasury

Fabricant, S. (1954) Economic progress and economic change, Washington, DC, National Bureau of Economic Research

Fare, R., S. Grosskopf and D. Margaritis (1996) 'Productivity growth' in A study of economic reform: the case of New Zealand, B. Silverstone, A. Bollard, and R. Lattimore, eds., Elsevier Science, New York

Farrell, M. (1957) 'The measurement of productive efficiency', Journal of the Royal Statistical Society, Series A, CXX, 253-81

Ganesan, S. (1984) 'Construction productivity', Habitat international, 8, 3-4

Mao, Z., B. H. Goh, S. Q. Wang and G. Ofori (2003) 'Total factor productivity growth accounting in the construction industry in Singapore', Construction Management and Economics, 21 (7), 707-718

Goodrum, P.M. and C.T. Haas (2004) 'Long-term impact of equipment technology on labor productivity in the U.S. construction industry at the activity level', Journal of construction engineering and management, 130 (1), 124-13

Grubb, D., Jackman, R., and R. Layard (1982) 'Causes of current stagflation', Review of economic studies, 44, 707-730

Haber, W. and H. Levinson (1956) Labor relations and productivity in the building trades, Ann Arbor, University of Michigan Press

Janssen, J. and S. McLoughlin (2008) New Zealand's productivity performance, New Zealand Treasury Productivity Paper 08/02, Wellington, the Treasury 
Kau, J.B. and Sirmans, C.F. (1983) 'Technological change and economic growth in housing', Journal or urban economics, 13, 283-95

Kendrick, J.W. (1956a) Productivity trends: capital and labor, Occasional Paper 53, Washington, DC, National Bureau of Economic Research

Kendrick, J.W. (1956b) The meaning and measurement of national productivity, PhD thesis. George Washington University, Washington D.C

Kendrick, J.W. (1961) Productivity trends in the United States, New York, NY, National Bureau of Economic Research/Princeton University Press

Kendrick, J.W. (1973) Post-war productivity trends in the United States 1948-1966, New York, NY, National Bureau of Economic Research

Kendrick, K.W. and C.E. Jones (1951) 'Gross National Farm product in constant dollars, 1910-1950', Survey of current business, 31, September, 12-19

Lowe, J.G. (1987) 'The measurement of productivity in the construction industry', Construction management and economics, 5, 115-21

Lovell, C.A. Knox and P. Schmidt (1988) 'A comparison of alternative approaches to the measurement of productive efficiency', in Applications of modern production theory: efficiency and productivity. eds. A. Dogramaci and R. Färe, Boston, Kluwer, Boston

Maloney, W. (1983) 'Productivity improvement: the influence of labor', Journal of construction engineering management, 109 (3), 321-334

Mason, G. and M. Osborne (2007) Productivity, capital-intensity and labour quality at sector level in New Zealand and the UK, New Zealand Treasury Working Paper 07/01, Wellington

Marks, P. (1984) 'The slowdown in labour productivity growth rates in New Zealand in the 1970s', in B. Easton, ed., Studies in the labour market, Wellington, NZIER

New Zealand, Department of Building and Housing, Productivity Taskforce (2009) Report of the Building and Construction Sector Productivity Taskforce: a modern efficient and productive New Zealand built infrastructure industry, Wellington, N.Z.: Dept. of Building and Housing

New Zealand, Productivity Commission (2011) Housing affordability inquiry: draft report, Wellington, Productivity Commission

New Zealand Institute of Economic Research (2011) Industry productivity and the AustraliaNew Zealand income gap, Wellington, Working paper 2011/3, NZIER

Orr, A. (1989) Productivity trends in New Zealand: a sectorial and cyclical analysis 19611987, Wellington, NZIER

Philpott, B. (1991) 'Economic growth in New Zealand models and Experience', in Long run perspectives on the New Zealand economy, Proceedings of the Sesquicentennial Conference of the New Zealand Association of Economists, New Zealand Association of Economists

Philpott, B. (1993) 'Data for sectorial productivity analysis and some preliminary results for 1978-93', RPEP Paper 256

Philpott, B. (1995) New Zealand's aggregate and sectoral productivity growth 1960-1995, Research project on economic planning paper 274, Victoria University of Wellington, October

Rosenfielde, S. and D.Q. Mills (1979) 'Is construction technologically stagnant?', in J.E. Lange and D.Q. Mills, eds., The construction industry, Lexington MA, D.C. heath and Company

Sarel, M. (1996) 'Growth and productivity in New Zealand', IMF internal paper 14, November 
Schmookler, J. (1952) 'The changing efficiency of the American economy, 18691938', Review of economics and statistics, 34 (3), 214-231

Schriver, W.R. and R.L. Bowlby (1985) 'Changes in productivity and composition of output in building construction, 1972-1982', Review of economics and statistics, 67 (2), 318-322

Schultz, C.L. (1959) Prices, costs and output for the post ware decade: 1947-1957, New York, Committee or Economic Development

Statistics New Zealand (2011) Gross domestic product, Wellington, Statistics New Zealand

Statistics New Zealand (2011) Household labour force survey, Wellington, Statistics New Zealand

Statistics New Zealand (2011) Industry productivity statistics, 1978-2009, Wellington, Statistics New Zealand

Stokes, H.K. (1981) 'An examination of the productivity decline in the construction industry', Review of economics and statistics, 63 (4), 495-502

Smith, R. and A. Grimes (1990) 'Sources of economic growth', Reserve Bank of New Zealand Bulletin, 53 (2), June, 140-48

Stigler, G.J. (1947) Trends in output and employment, National Bureau of Economic Research, University of Princeton Press

Stigler, G.J. (1961) 'Economic problems in measuring changes in productivity', In Output, input and productivity measurement, Conference on Research in Income and Wealth, UMI

Tan, W. (2000) 'Total factor productivity in Singapore construction', Engineering, construction and architectural management, 7 (2), 154-158

Thomas, H. and A. Sakarcan (1994) 'Forecasting labor productivity using factor model', Journal of construction engineering management, 120 (1), 228-239

Thomas, H., Maloney, W., Horner, R., Smith, G., Handa, V., and Sanders, S. (1990) 'Modelling construction labor productivity', Journal of construction engineering management, 116 (4), 705-726

Van Dai Tran (2010) Exploring construction productivity statistics in New Zealand, Master of Engineering thesis, Auckland University of Technology, Auckland

Wang, Y.S. (1998) An analysis of the technical efficiency in Hong Kong's construction industry, unpublished PhD thesis, University of Hong Kong, Hong Kong

Wang, Y.S. and K.W. Chau (1997) 'An evaluation of the technical efficiency of construction industry in Hong Kong using the DEA approach', Proceedings of ARCOM97 Conference, Cambridge, 690-701

Wang, Y.S. and K.W. Chau (2001) 'An assessment of the technical efficiency of construction firms in Hong Kong', International journal of construction management, 29,105-122 